\title{
Roads support the spread of invasive Asclepias syriaca in Austria
}

\author{
Straßenränder fördern die Ausbreitung \\ von Asclepias syriaca in Österreich
}

\author{
Swen Follak ${ }^{1 *}$, Corina Schleicher ${ }^{2}$, Michael Schwarz $^{3}$
}

\footnotetext{
${ }^{1}$ Austrian Agency for Health and Food Safety, Institute for Sustainable Plant Production, Spargelfeldstraße 191, 1220 Vienna, Austria

${ }^{2}$ Austrian Agency for Health and Food Safety, Data, Statistics and Risk Assessment, Zinzendorfgasse 27, 8010 Graz, Austria

${ }^{3}$ Austrian Agency for Health and Food Safety, Data, Statistics and Risk Assessment, Spargelfeldstraße 191, 1220 Vienna, Austria

* Corresponding author: swen.follak@ages.at
}

Received: 3 October 2018, received in revised form: 10 December 2018, accepted: 10 December 2018

\begin{abstract}
Summary
Asclepias syriaca is an invasive alien plant that has recently spread in Central Europe. The spatiotemporal spread of $A$. syriaca was reconstructed based on the distribution data for Austria. A. syriaca has increased in abundance and range, especially after the year 2005. At present, the species occurs primarily in eastern Austria (Vienna, Lower Austria), while it was rarely recorded in southern and western Austria. Further spread and range filling is probable. Moreover, the distribution of $A$. syriaca along roadsides and the role of road type and adjoining land use in facilitating its spread were studied in an area of high presence of the species in Lower Austria in 2018. It was shown that $A$. syriaca occurred regularly along roadsides and the chance of finding $A$. syriaca was higher along unpaved roads and along roadsides bordered by forests and grassland. The results indicate that the road network contributes to the spread of A. syriaca in the study area, most likely by providing suitable and well connected habitats. If $A$. syriaca densities are to be lowered, emphasis should be placed on both a proper roadside management (e.g., mowing regimes) and on the control of the species in the respective adjacent habitat.
\end{abstract}

Keywords: distribution, invasive alien plants, land use, management, roadside

\section{Zusammenfassung}

Asclepias syriaca ist eine invasive Pflanze, die sich in Mitteleuropa ausbreitet. In dieser Studie wurde die räumlich-zeitliche Ausbreitung von A. syriaca in Österreich anhand von Verbreitungsdaten untersucht. Fundorte von A. syriaca haben nach 2005 deutlich zugenommen und eine weitere Ausbreitung ist wahrscheinlich. Gegenwärtig kommt die Art insbesondere in Ostösterreich (Wien, Niederösterreich) und nur spärlich in West- und Südösterreich vor. Darüber hinaus wurde das Vorkommen der Pflanze entlang von Straßenrändern in einer landwirtschaftlich geprägten Region in Niederösterreich im Jahr 2018 erhoben und der Einfluss des Straßentyps und der angrenzenden Landnutzung auf ihre Ausbreitung untersucht. A. syriaca wurde häufig an Straßenrändern beobachtet und die Chance war am größten, die Art an nicht asphaltierten Straßen und entlang von Straßen mit angrenzenden Wäldern und Grasland zu finden. Die Ergebnisse zeigen, dass das Straßennetzwerk einen wesentlichen Einfluss auf die Ausbreitung von A. syriaca in dem Untersuchungsgebiet hat. Der Schwerpunkt des Managements der Art sollte auf einer fachgerechten Bekämpfung entlang der Straßenränder (u.a. kontinuierliche Mahd) liegen, gleichzeitig müssen aber auch die angrenzenden Habitate miteinbezogen werden.

Schlagworte: Verbreitung, Invasive gebietsfremde Pflanzen, Landnutzung, Straßenränder, Bekämpfung 


\section{Introduction}

Road corridors have become a focus of ecological research because of their impact on surrounding ecosystems in regions with dense road networks as well as in rural landscapes. Ecological issues involve habitat fragmentation, soil erosion, edge effects, pollution, and, more recently, the invasion of exotic species (Forman et al., 2003). Follak et al. (2018) provided a snap-shot of invasive alien plants currently found along roadsides in Europe, highlighting the importance of roadsides as conduits for the spread of invasive alien plants. The corridor-like nature of road infrastructure provides invasive alien plants with the opportunity to spread naturally over long distances without facing barriers for dispersal (Christen and Matlack, 2006). Roadsides are usually well drained, open habitats that are frequently disturbed by maintenance activities (vegetation mowing, drainage, ditch cleaning), which creates environmental conditions in which invasive alien plants thrive (Forman et al., 2003). Invasive alien plants may also escape from the roadside and colonize adjacent natural or anthropogenic habitats.

At present, a few studies have scrutinized distribution patterns of major invasive alien plants along roadsides in Europe. For example, there is evidence that road networks have contributed to the spread of the invasive Ambrosia artemisiifolia (common ragweed) in Austria (Essl et al., 2009) and Germany (Lemke et al., 2018). In Central Europe, the recent spread pattern of Senecio inaequidens (South African ragwort) revealed its preferential migration along motorways (Glasnović and Pećnikar, 2010; Kocián, 2016). Although there are numerous factors (e.g., traffic density, type, and intensity of road management) that influence the spread of invasive alien plants along roadsides (Forman et al., 2003; Lemke et al., 2018), the role of the road type and adjacent land use is potentially important (Follak et al., 2018). For example, in southern Quebec (Canada), Joly et al. (2011) showed that $A$. artemisiifolia was commonly found along regional and local paved roads while unpaved local roads were rarely colonized. Meunier and Lavoie (2012) pointed out that crop fields, wasteland, and construction sites next to the roadside may permit the spread of invasive Galium mollugo (smooth bedstraw).

Asclepias syriaca (common milkweed) is native to North America (Bagi, 2008), and since 2017, it is on the List of Invasive Alien Species of Union Concern (http://data. europa.eu/eli/reg_impl/2017/1263/oj). Thus, there is an obligation for the control of this species. A. syriaca is a strong competitor because it develops large, dense, and persistent populations (Bagi, 2008) and it has effective chemical defense mechanisms against herbivory (Agrawal, 2004). It has become increasingly abundant in central and southern Europe (e.g., Bagi, 2008; Pauková et al., 2014; Rutkowski et al., 2015; Popov, 2016; Dvirna, 2018). In Austria, its spatiotemporal distribution has not been systematically investigated, although the species is considered to be at an early stage of invasion. It is likely that $A$. syriaca may become more widespread in the future aided by its strong colonizing abilities (Bagi, 2008). Moreover, the species has recently been recognized locally along Austrian roadsides (Sengl and Rehorska, 2017; Follak, pers. obs.). But whether $A$. syriaca has the ability to invade roadsides to a larger extent and how it can be effectively controlled need to be determined.

Therefore, the objectives of this study were to (1) analyze the spatiotemporal distribution of $A$. syriaca in Austria, (2) sample roadsides in order to estimate the abundance and distribution of $A$. syriaca, (3) determine the role of the road type and adjacent land use in the occurrence and spread of A. syriaca in a selected agricultural region of Austria, and (4), finally, to propose management options along roadsides.

\section{Material and methods}

\subsection{Study species}

A. syriaca is a fast growing, perennial, dicotyledonous species native to the eastern lowlands of North America. The species was brought to Europe as an ornamental plant and also for economic utilization (e.g., latex production) in the 19th century, and by now, it has become naturalized in central and southern European countries (Bagi, 2008). In its invaded range, $A$. syriaca is mainly found in ruderal habitats (railway tracks, roadsides) and on abandoned agricultural land, deforested areas, or degraded areas (Kelemen et al., 2016; Rutkowski et al., 2015). So far, A. syriaca was only sporadically found in crop fields, vineyards, and orchards in Austria (Follak, unpublished data), although the species is a common weed in neighboring countries such as Hungary (Novák et al., 2009) and in its native range (Hartzler and Buhler, 2000). Propagation of A. syriaca occurs through seeds and rhizomes. Reproductive stems may have about two to three follicles, and each of it contains up to 200 seeds with long white flossy hairs that are perfectly 
adapted to wind dispersal. The roots and rhizomes form a large and dense underground network spreading out from the mother plant. Both traits are significantly associated with its colonization ability (Bagi, 2008). A. syriaca is found in well drained soils of all textural groups, especially on sand and sandy loess (Bagi, 2008). The biology and ecology of $A$. syriaca have been summarized in detail by Bagi (2008) and Bhowmik (1994) with a focus on Central Europe and North America, respectively.

\subsection{Data sources and analysis}

Records for Austria have been collated from 1990 until 2018. A wide range of sources has been used (e.g., floristic literature, floristic databases, and unpublished record from experts and botanists). All records were cross-checked to avoid double entries of identical records stored repeatedly in different data sources. The year of the records was extracted from the original data source. A database incorporating 82 records was created for this study. All records were assigned to a grid cell $\left(5 \times 3\right.$ geographic minutes, $\left.-33 \mathrm{~km}^{2}\right)$ of the Floristic Mapping Project of Central Europe (Niklfeld, 1999). Maps indicating the spatial distribution of the study species for two time periods (1990-2005 and 2006-2018) were produced based on the grid cells occupied.

In parts of the Marchfeld region (Lower Austria), the distribution and abundance of $A$. syriaca along roadsides and the role of road type and adjoining land use in facilitating its spread were studied in detail. This area was selected, because the main occurrences of $A$. syriaca in Austria can be found in this region (Figure 1). The climate is temperate pannonic, with cool winters and warm summers, average annual temperature and precipitation being $9.8^{\circ} \mathrm{C}$ and $520 \mathrm{~mm}$, respectively (reference place: Groß-Enzersdorf, $\left.48^{\circ} 11^{\prime} 47.2^{\prime \prime} \mathrm{N} 16^{\circ} 33^{\prime} 17.3^{\prime \prime} \mathrm{E}, 1971-2000\right)$. The study area $\left(87.5 \mathrm{~km}^{2}\right)$ is dominated by agriculture, with some interspersed forests, gravel pits and settlements.

The total length of the road network was $320.6 \mathrm{~km}$ (2018, http://www.gip.gv.at/), excluding motorway S1, which was not sampled for safety reasons (heavy traffic volume). The road network has been categorized into three road types: (1) regional paved ("Landesstraße L", "Landesstraße B", length: $64.4 \mathrm{~km}$ ), (2) local paved, and (3) local unpaved ("Gemeindestraße", "other street categories", length: $256.2 \mathrm{~km}$ ). A map of the study area was subdivided into $100 \mathrm{~m} \times 100 \mathrm{~m}(1 \mathrm{ha})$ grid cells. Each grid cell of a predefined route $(\mathrm{n}=1451)$ was classified according to the presence/absence of a particular road type (i.e., regional paved, local paved, and local unpaved). Commonly, A. syriaca emerges from late April to mid-June (Follak, pers. obs.; Bagi, 2008). Thus, the route was visited in May/June 2018 , that is, the time of year when new shoots have already emerged and are particularly visible, and before the mowing season started. Populations of $A$. syriaca were recorded along the roadsides, and each location was georeferenced. A roadside was defined as the area laterally from the pavement or the vegetation-free driving surface of unpaved roads to the adjoining land-use type (Forman et al., 2003). A map indicating the distribution of $A$. syriaca along roadsides was produced based on the sampled locations using ArcGIS 10.6. A high-resolution habitat distribution map (Kuttner et al., 2015) was used to determine the adjoining land use type. The midpoint of each grid cell was chosen for the presence/absence of the adjacent land use type. In this study, the different adjacent land use types have been merged to the following four categories: "built up areas", "arable land" (including orchards), "grassland" (extensive grassland, intensively used grassland), and "forests" (coniferous forest, broad-leaved forest, dry biotypes). Moreover, grid cells with a railway track inside were listed separately in order to analyze their potential role in the distribution of $A$. syriaca.

A generalized linear model (binomial regression model) was used to model the probability of finding A. syriaca in a grid cell depending on the abovementioned variables, road type and adjoining land use type (Gelman and Hill, 2007). Significance of predictor variables was tested by likelihood ratio tests. The generalized linear model was implemented in $\mathrm{R}$, version 3.4.4 ( $\mathrm{R}$ Core Team, 2018).

\section{Results}

\subsection{Spatiotemporal distribution in Austria}

In total, 82 records of $A$. syriaca from 52 grid cells of the Floristic Mapping Project of Austria were obtained (Figure 1). At present, A. syriaca is not widely distributed in Austria. The species occurs primarily in eastern Austria (Vienna, Lower Austria). Large and naturalized populations can be particularly found in parts of the Marchfeld region (Lower Austria) (Figure 1). Recently, a few scattered populations were observed in the Graz basin and Drau valley in Styria and Carinthia, respectively. In western Austria, records of the species were rare and almost restricted to a few isolated populations (e.g., in the cities of Salz- 

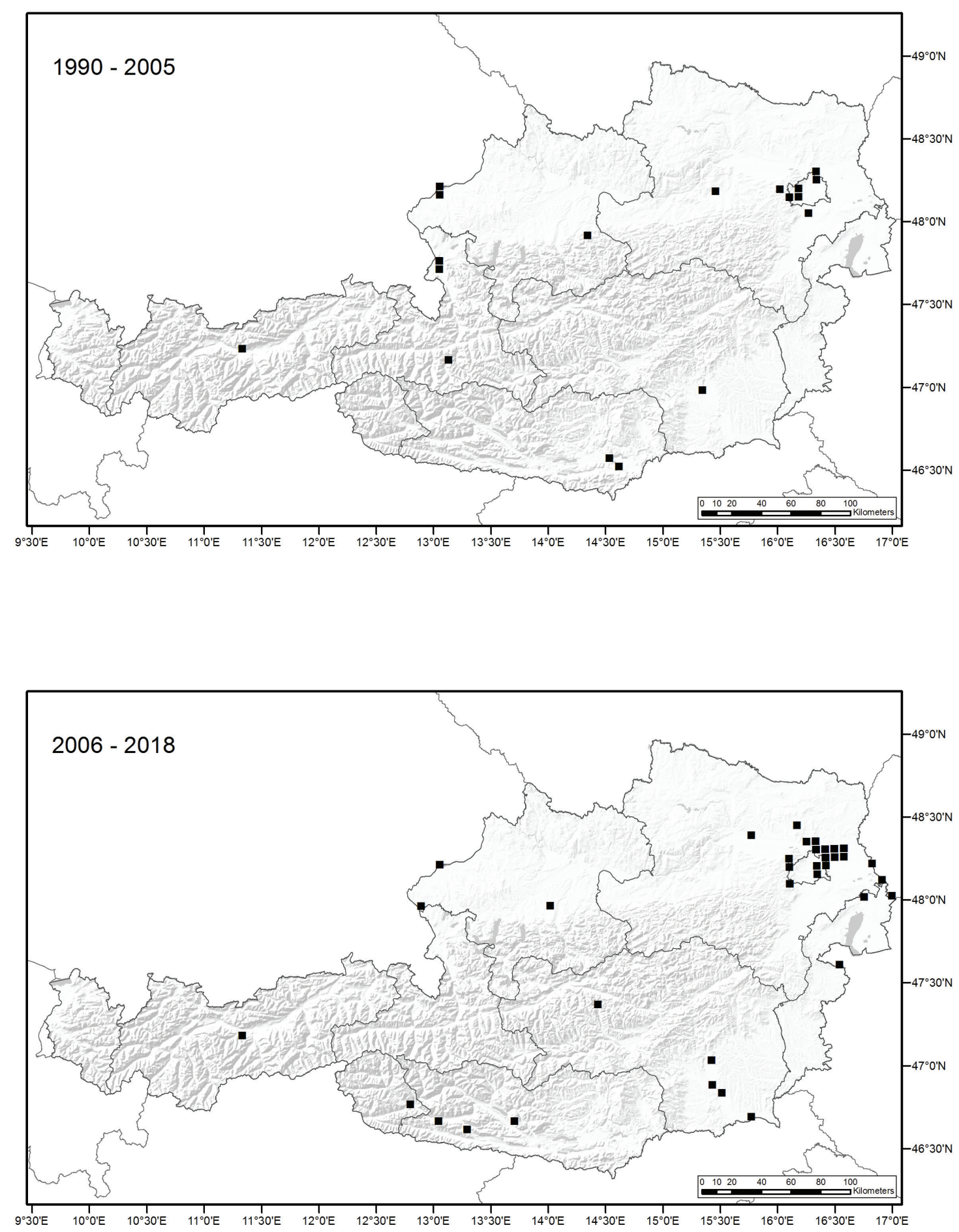

Figure 1. Distribution map of Asclepias syriaca in Austria for the time periods 1990-2005 and 2006-2018 based on the grid cells of the Floristic Mapping of Central Europe (cell size: $5 \times 3$ geographic minutes, $-33 \mathrm{~km}^{2}$ ).

Abbildung 1. Verbreitungskarte von Asclepias syriaca in Österreich für die Zeitperioden 1990-2005 und 2006-2018 basierend auf dem Quadrantenraster der Floristischen Kartierung Mitteleuropas (Rasterzelle: $5 \times 3$ geographische Minuten, $-33 \mathrm{~km}^{2}$ ). 
burg, Innsbruck). However, the results indicate that the species has spread over time in terms of the number of occupied grid cells. Their number increased from 20 (in 1990-2005) to 36 (in 2006-2018) (Figure 1).

\subsection{Abundance and distribution along roadsides in the Marchfeld region}

A total of 78 populations of $A$. syriaca were recorded, and they were almost evenly distributed throughout the study area (Figure 2). A. syriaca was found along the roadsides of all road types (Figures 2 and $3 \mathrm{a}-\mathrm{c}$ ). Population size varied from solitary and small populations $(<25$ stems/population) to large populations several meters in length along the roadside (data not shown). The probability of recording $A$. syriaca was significantly higher $(\mathrm{p}<0.001)$ along a local unpaved road than along the two other road types (Table 1). Compared to roads with adjoining "built up areas", the model also indicated that in 2018 , there were significantly higher odds of finding an $A$. syriaca population along a road in a grid cell with "forests" $(\mathrm{p}=0.003)$ and "grassland" ( $\mathrm{p}=0.006)$ as an adjoining land use type. In addition, the odds of finding $A$. syriaca in a grid cell along a road with "arable land" as the adjoining land use type was higher compared to the reference category "builtup areas". However, with a p-value of 0.083 , this was not significant at the 5\% significance level. Moreover, in grid cells where a railway track was present, the chance of finding an A. syriaca population was also significantly higher $(\mathrm{p}=0.007)$.

\section{Discussion}

\subsection{Spatiotemporal distribution in Austria}

A. syriaca is currently most abundant in a small part in the eastern lowlands of Austria. Early occurrences of the species from this particular area were described by Janchen (1977). Since then, it locally spread as indicated by the occupation of adjacent grid cells in the recent years (Figure 1). It seems that short-distance spread has become a dominant mechanism of range expansion for $A$. syriaca. Its rapid spread in this particular area was most likely assisted by the development of the road network (motorway and interchanges) that was carried out between 2007 and 2009 and gravel mining. Road construction (Figure 3d), landscaping, and mining caused disturbed soil and barren sites

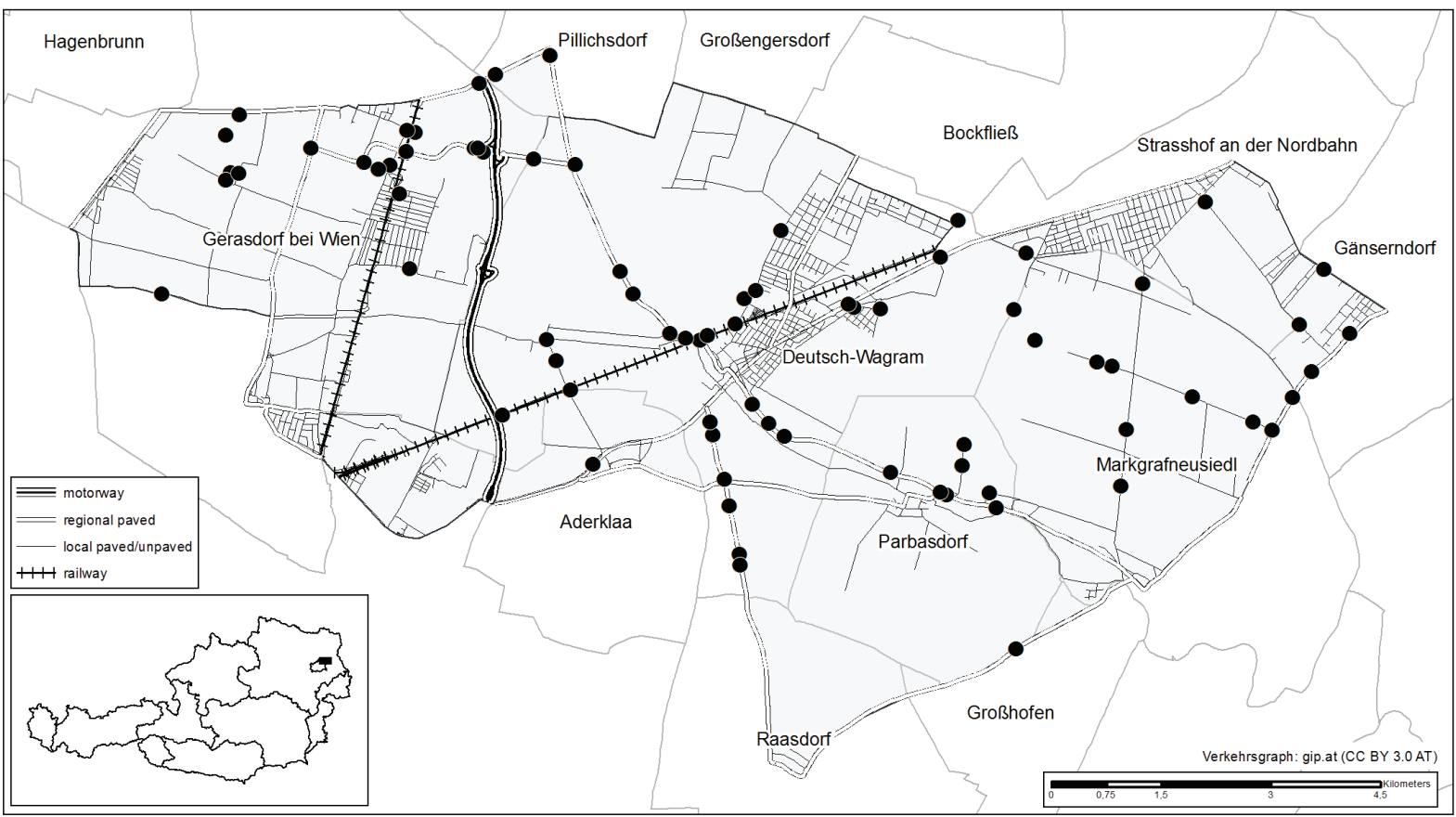

Figure 2. Distribution of Asclepias syriaca along roadsides in an agricultural region in eastern Austria $(\bullet=$ population of $A$. syriaca, $\mathrm{n}=78)$. Abbildung 2. Vorkommen von Asclepias syriaca entlang von Straßen in einer landwirtschaftlich geprägten Region in Ostösterreich $(\bullet=A$. syriacaPopulation, $\mathrm{n}=78)$. 

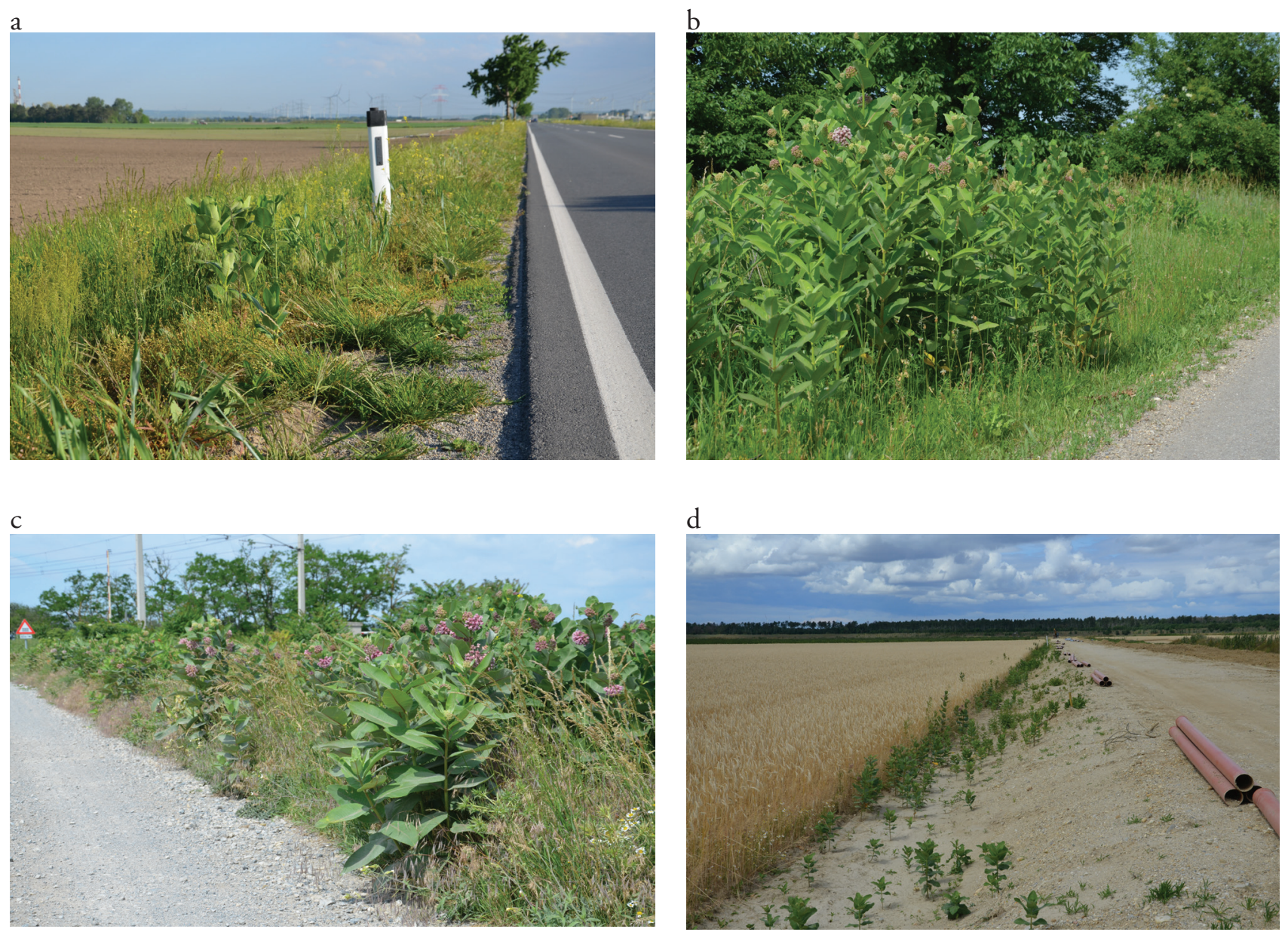

Figure 3. The three different road types invaded by Asclepias syriaca in the study area: (a) regional paved, (b) local paved, (c) local unpaved; (d) spread of $A$. syriaca during road construction.

Abbildung 3. Die drei unterschiedlichen Straßentypen mit einem Befall von Asclepias syriaca in dem Untersuchungsgebiet: (a) Landesstraße asphaltiert, (b), Gemeindestraße asphaltiert, (c) Gemeindestraße nicht asphaltiert; (d) Ausbreitung von A. syriaca durch den Straßenbau.

creating environmental conditions that were favorable to A. syriaca (Bagi, 2008). Recent observations of $A$. syriaca in other parts of Austria may be attributed to former cultivation for beekeeping or as an ornamental plant (e.g., Sengl and Rehorska, 2017) and, likewise, were probably human mediated by unintended transport of rhizome fragments by contaminated soil.

Kleinbauer et al. (2010) showed that $A$. syriaca currently occupies less than $1 \%$ of all the potentially suitable area (grid cells) in Austria. In particular, in the southern part where only a few records are presently available, further spread and range filling is probable. The western part of Austria (alpine foreland, valleys in the Alps) is less climatically suitable, which is also indicated by the few occupied grid cells (Figure 1). Similarly, in the Czech Republic, the species is most abundant and invasive only in the warm lowlands, in particular in southern Moravia (Kaplan et al., 2017). In Hungary and Serbia, the species is also confined to the warmer regions (Hungarian Great Plain, Vojvodina; Bagi, 2008; Popov, 2016).

\subsection{Abundance and distribution along roadsides in the Marchfeld region}

In its native range, $A$. syriaca is a common element of the roadside vegetation (e.g., Hartzler and Buhler, 2000). In its invaded range, likewise in the Marchfeld region, the species can be found along roadsides in neighboring countries such as Hungary (Bagi, 2008), Slovakia (Pauková et al., 2014), the Czech Republic (Kaplan et al., 2017), Serbia (Popov, 2016), Poland (Rutowski et al., 2015), and the Ukraine (Dvirna, 2018). The specific ecological properties 
Table 1. Estimated model parameters of the generalized linear model (GLM)

Tabelle 1. Geschätzte Modellparameter des Generalisierten linearen Modelles (GLM)

\begin{tabular}{lccc}
\hline Parameters & Estimated coefficient & SE & p-Value \\
\hline (Intercept) & -3.6616 & 0.2733 & $<0.001$ \\
Local unpaved road & 0.9765 & 0.2828 & $<0.001$ \\
Adjoining land use & & & 0.083 \\
$\quad$ Arable land & 0.5648 & 0.3263 & 0.003 \\
Forests & 1.6075 & 0.5480 & 0.006 \\
$\quad$ Grassland & 1.4721 & 0.5303 & 0.007 \\
Railways & 1.1587 & 0.4277 & \\
\hline
\end{tabular}

$\mathrm{SE}=$ standard error

of roadsides (e.g., light and soil conditions) seem to favor $A$. syriaca, and, concurrently, it is also believed that its life history characteristics (i.e., rhizomes up to $1 \mathrm{~m}$ depth) buffer the species against harsh environmental conditions (e.g., drought). The results of the survey in the Marchfeld region showed that $A$. syriaca occurred along roadsides in spatially limited populations up to larger ones extending several square meters. This reflects the vegetative propagation of the species by its rhizomes that allow the production of large clonal populations (Bagi, 2008).

\subsection{Factors promoting spread along roadsides in the Marchfeld region}

The role of the road type is potentially important for the spread of invasive alien plants (Joly et al., 2011). The results indicated that $A$. syriaca has a comparatively higher preference for local unpaved roads. In this study, local unpaved roads were in part characterized by high disturbance of the upper soil layer along the road verges (specifically in the mining areas) providing beneficial growth conditions for $A$. syriaca. Roadsides of high-ranking roads (i.e., regional paved road type; to some extent, also the local paved road type) are generally covered by dense vegetation (grasses) and mown if necessary (i.e., more than twice a year, throughout the growing season). Less open ground, competition, and the high frequency of mowing may influence the establishment and performance of $A$. syriaca. However, Bhowmik (1994) pointed out that mowing (cutting) leads to the formation of larger colonies of $A$. syriaca by inducing lateral root buds to sprout. Indeed, Zalai et al. (2017) demonstrated that shoots of $A$. syriaca were able to regrow and recover within 2 weeks after repeated cutting in a nature conservation area in Hungary.

In addition, $A$. syriaca can be found along railway tracks in the study area (Figure 2), and the model also suggests that grid cells with railway tracks are significantly more populated by $A$. syriaca than without (Table 1). Similarly, railway construction (upgrading, station renewal along the railway) in the past decade may have fostered its local spread. Moreover, the turbulence of passing trains may have enhanced the wind dispersal of its seed and the colonization of other habitats including roadsides (Csontos et al., 2009). Railway tracks are also a typical habitat for A. syriaca in other countries (e.g., Rutowski et al., 2015). The results reveal that specific adjacent land use types foster the presence and spread of $A$. syriaca along roadsides. More particularly, a roadside crossing a grid cell dominated by "forests" and "grassland" seemed to be more likely invaded by $A$. syriaca than a roadside surrounded by "arable land" and "built up areas". In the study area, the lowland temperate forests (mainly stands of Robinia pseudoacacia, Quercus sp. and Pinus sp.) are broadly characterized by poor growth, and their relatively open canopy (in particular at the forest edge) allow light-demanding species such as $A$. syriaca to thrive in the undergrowth and to build up large populations (Essl et al., 2012). Likewise, extensively used grassland and abandoned fallow land (e.g., old fields) are hotspots for the establishment and expansion of $A$. syriaca because of former soil disturbance and nutrient enrichment, respectively (Kelemen et al., 2016). Thus, there is a high pressure from these populations of invading adjacent roadsides, and equally, roadside populations of $A$. syriaca can certainly establish in the forest and grassland habitats. The species has a high colonization ability because of its wind-dispersed seeds and rhizomes that can spread for a distance of $>1 \mathrm{~m} /$ year from the point of origin (Bhowmik, 1994). "Arable land" as an adjacent land use type seems to have not an important influence on the presence of $A$. syriaca. Large infestations of crop fields along roadsides have not been frequently observed, yet, most likely because of intensive farming (i.e., high level of herbicide input, soil 
cultivation) in large parts of the study area. Populations of A. syriaca were commonly restricted to the field border of the crop field next to a roadside (Follak, pers. obs.). This, however, suggests that populations of $A$. syriaca intruded the crop fields by vegetative spread. Nevertheless, when infested crop fields are cultivated or harvested, machinery and vehicles can spread rhizome fragments of $A$. syriaca to and along roadsides.

\subsection{Management options along roadsides in the Marchfeld region}

Control of the species is legally binding, as it is categorized as an Invasive Alien Species of Union Concern (http:// data.europa.eu/eli/reg_impl/2017/1263/oj). Problems arise when roadside populations spread into crop fields (Hartzler and Buhler, 2000) or natural habitats of nature conservation value (Kelemen et al., 2016). Moreover, it may also be problematic for road safety, because it forms dense stands (Figures $3 b$ and $3 c$ ) that may prevent drivers from recognizing traffic signs (e.g., delineator posts) as well as wild animals.

How can the expansion of $A$. syriaca along roadsides be prevented? It is generally believed that it is difficult to get rid of established $A$. syriaca populations because of the large root network (Bhowmik, 1994). Mowing is the chosen option for vegetation control along roadsides in Austria. An effective long-term control of $A$. syriaca might best be secured by continuous mowing that repeatedly destroys the shoots of the plant and thus depletes stored carbohydrate reserves in the root system (Bhowmik, 1994). However, optimal and frequent cutting dates need to be determined and cannot always be achieved in practice because of organizational challenges for road maintenance depots and the increase in workload and costs. In this respect, $A$. syriaca is supposed to be more susceptible to mowing before flowering than at an early growth stage (Zalai et al., 2017). Although herbicides can be used to control the species (e.g., Bhowmik, 1994; Zalai et al., 2017), they are generally not used along roadsides in Austria. If $A$. syriaca densities are to be lowered in the study area and elsewhere, emphasis should be placed on a proper roadside management (e.g., continuous mowing, removal of $A$. syriaca populations followed by seeding fast-growing and/or competitive plant species; Schuster et al., 2018) and the control in the respective adjacent habitat (periodic maintenance of old fields, control along the crop field border by spot treatment and/or frequent soil cultivation; Bhowmik, 1994).

\section{Acknowledgments}

Distribution data were provided by R. Diran, F. Essl and F. Polesny whose help is greatly acknowledged. We thank two anonymous reviewers for their helpful comments on the manuscript.

\section{References}

Agrawal, A.A. (2004): Resistance and susceptibility of milkweed: competition, root herbivory, and plant genetics. Ecology 85, 2118-2133.

Bagi, I. (2008): Common milkweed Asclepias syriaca L. In: Botta-Dukát Z. and L. Balogh (Eds.): The Most Important Invasive Plants in Hungary. Institute of Ecology and Botany, Hungarian Academy of Sciences, Vácrátót, pp. 151-159.

Bhowmik, P.C. (1994): Biology and control of common milkweed (Asclepias syriaca). Reviews of Weed Science 6, 227-250.

Christen, D. and G. Matlack (2006): The role of roadsides in plant invasions: a demographic approach. Conservation Biology 20, 385-391.

Csontos, P., Bózsing, E., Cseresnyés, I. and K. Penksza (2009): Reproductive potential of the alien species $A s$ clepias syriaca (Asclepiadaceae) in the rural landscape. Polish Journal of Ecolology 57, 383-388.

Dvirna, T.S. (2018): Asclepias syriaca L. in the RomenskoPoltavsky Geobotanical District (Ukraine). Russian Journal of Biological Invasions 9, 29-37.

Essl, F., Dullinger, S. and I. Kleinbauer (2009): Changes in the spatio-temporal patterns and habitat preferences of Ambrosia artemisiifolia during its invasion in Austria. Preslia 81, 119-133.

Essl, F., Mang, T. and D. Moser (2012): Ancient and recent alien species in temperate forests: steady state and time lags. Biological Invasions 14, 1331-1342.

Follak, S., Eberius, M., Essl, E., Fürdös, A., Sedlacek, N. and F. Trognitz (2018): Invasive alien plants along roadsides in Europe. EPPO Bulletin 48, 256-265.

Forman, R.T.T., Sperling, D., Bissonette, J.A., Clevenger, A.P., Cutshall, C.D., Dale, V.H. et al. (2003): Road Ecology. Science and Solutions. Island Press, Washington, D.C.

Gelman, A. and J. Hill (2007): Data Analysis using Regression and Multilevel/Hierarchical Models. Cambridge University Press, Cambridge, UK. 
Glasnović P. and F. Pećnikar (2010): Akebia quinata (Houtt.) Dcne., nova vrsta v slovenski flori, ter prispevek $\mathrm{k}$ poznavanju neofitske flore Primorske. Hladnikia 25, 31-43.

Hartzler, R.G. and D.D. Buhler (2000): Occurrence of common milkweed (Asclepias syriaca) in cropland and adjacent areas. Crop Protection 19, 363-366.

Janchen, E. (1977): Flora von Wien, Niederösterreich und Nordburgenland. Verein für Landeskunde von Niederösterreich und Wien, $757 \mathrm{pp}$.

Joly, M., Bertrand, P., Gbangou, R.Y., White, M.-C., Dube, J. and C. Lavoie (2011): Paving the way for invasive species: Road type and the spread of common ragweed (Ambrosia artemisiifolia). Environmental Management 48, 514-522.

Kaplan, Z., Danihelka, J., Koutecký, P., Šumberová, K., Ekrt, L., Grulich, V., Repka, R., Hroudová, Z., Štěpánková J., Dvořák, V., Dančák, M., Dřevojan, P. and J. Wild (2017): Distributions of vascular plants in the Czech Republic. Part 4. Preslia 89, 115-201.

Kocián, P. (2016): The first records of Senecio inaequidens along motorways in Poland and Slovakia. Acta Musei Silesiae, Scientiae Naturales 65, 129-133.

Kelemen, A., Valkó, O., Kröel-Dulay, G., Deák, B., Török, P., Tóth, K., Migléc, T. and B. Tóthmérész (2016): The invasion of common milkweed (Asclepias syriaca L.) in sandy old-fields - Is it a threat to the native flora? Applied Vegetation Science 19, 218-224.

Kleinbauer, I., Dullinger, S., Klingenstein, F., Mayr, R., Nehring, S. and F. Essl (2010): Ausbreitungspotenzial ausgewählter neophytischer Gefäßpflanzen unter Klimawandel in Deutschland und Österreich. BfNSkripten 275, http://www.bfn.de/0502_artenschutz. html. Accessed on 30 March 2018.

Kuttner, M., Essl, F., Peterseil, J., Dullinger, S., Rabitsch, W., Schindler, S., Hülber, K., Gattringer, A. and D. Moser (2015): A new high-resolution habitat distribution map for Austria, Liechtenstein, southern Germany, South Tyrol and Switzerland. eco.mont - Journal on Protected Mountain Areas Research and Management 7, 18-29.

Lemke, A., Kowarik, I. and M. von der Lippe (2018): How traffic facilitates population expansion of invasive spe- cies along roads: The case of common ragweed in Germany. Journal of Applied Ecology, doi 10.1111/13652664.13287.

Meunier, G. and C. Lavoie (2012): Roads as corridors for invasive plant species: new evidence from smooth bedstraw (Galium mollugo). Invasive Plant Science and Management 5, 92-100.

Niklfeld, H. (1999): Mapping the flora of Austria and the eastern Alps. Revue Valdôtaine d'Histoire Naturelle 51, 53-62.

Novák, R., Dancza, I., Szemtey, L. and N.J. Karma (2009): Arable weeds of Hungary. The $5^{\text {th }}$ National Weed Survey (2007-2008). Ministry of Agriculture and Rural Development, Budapest, Hungary.

Pauková Ž., Knápeková M. and M. Hauptvogl (2014): Mapping of alien species of Asclepias syriaca and Fallopia japonica populations in the agricultural landscape. Journal of Central European Agriculture 15, 12-22.

Popov, M. (2016): Rasprostranjenost, bioloske karakteristike i suzbijanje Asclepias syriaca L. PhD Thesis, University of Novi Sad, Serbia.

R Core Team (2018): R: A language and environment for statistical computing. R Foundation for Statistical Computing, Vienna, Austria. Available at: https:// www.R-project.org/.

Rutkowski, L., Kaminski, D., Nienartowicz, A., FilbrandtCzaja, A., Adamska, A. and M. Deptuła (2015): New localities and habitat preferences of common milkweed Asclepias syriaca L. in Torun (Central Poland). Ecological Questions 22, 75-86.

Sengl, P. and R. Rehorska (2017): Asclepias syriaca, Gewöhnliche Seidenpflanze (Asclepiadaceae) - Ein Neubürger der südlichen Steiermark mit Ausbreitungspotential. Mitteilungen des Naturwissenschaftlichen Vereines für Steiermark 147, 67-76.

Schuster, M.J., Wragg, P.D. and P.B. Reich (2018): Using revegetation to suppress invasive plants in grasslands and forests. Journal of Applied Ecology 55, 2362-2373.

Zalai, M., Poczok, L., Dorner, Z., Körösi, K., Pálinkás, Z., Szalai M. and O. Pintér (2017): Developing control strategies against common milkweed (Asclepias syriaca L.) on ruderal habitats. Herbologia 16, 69-84. 